\title{
Examining Property Tax Value Assessment Error
}

\author{
Marcus T. Allen \\ Lutgert College of Business, Florida Gulf Coast University, Fort Myers, FL, United States \\ Email: timallen@fgcu.edu
}

\begin{abstract}
Accuracy in the value assessment process in ad valorem property tax systems is of paramount importance to equitable treatment of taxpayers, yet several previous studies suggest that assessors' opinions of value may be systematically biased. This study uses a large sample of properties that were assessed within one year after an arm's length transaction with observed prices to test whether task complexity affects the accuracy of assessors' opinions of value. The results provide evidence that property characteristics and location factors impact the magnitude of assessment error.
\end{abstract}

Keywords: Property tax; assessment error; market value

\section{Introduction}

Conceptually, assessment error exists when an assessor's opinion of market value differs from the true market value of the property. Practically, measurement of assessment error is difficult because true market value is a theoretical construct that is not directly observable. As Geltner and Ling [1] explain, true market value exists for all properties at all points in time, but true market value is not empirically observable. At best, market participants can observe occasional transaction prices for properties and, when the transaction conditions are consistent with the notion of a well-functioning market, can consider observed transaction prices as individual draws from the underlying probability distributions that are centered around the unobservable true market values of the properties.

Even in well-functioning markets, observed transaction prices can be considered to exhibit crosssectional dispersion around true market values because market participants themselves cannot know exactly at what price a property "should" be traded. Asymmetric information, motivations, negotiating skills, and plain old "luck" may result in transactions in which either the buyer or seller gets a "better deal."

Just as transaction prices can be considered randomly dispersed around true market values, assessed values are also randomly dispersed around true market value, but assessed value dispersion may not necessarily be centered around true market value. Instead, assessed values may be systematically biased by information that is available about the property and/or market conditions to the assessor at the time the value opinion is formed or by incompetence, negligence, or impropriety on the part of the assessor.

The research question addressed in this study is whether determinants of assessor error can be detected through empirical analysis of assessed values and transaction prices of properties recently sold in arm's length transactions. Analysis of a large sample of properties that were assessed within one year after arm's length transactions involving each property supports the notion that the complexity of the assessment task contributes to the magnitude of assessment error.

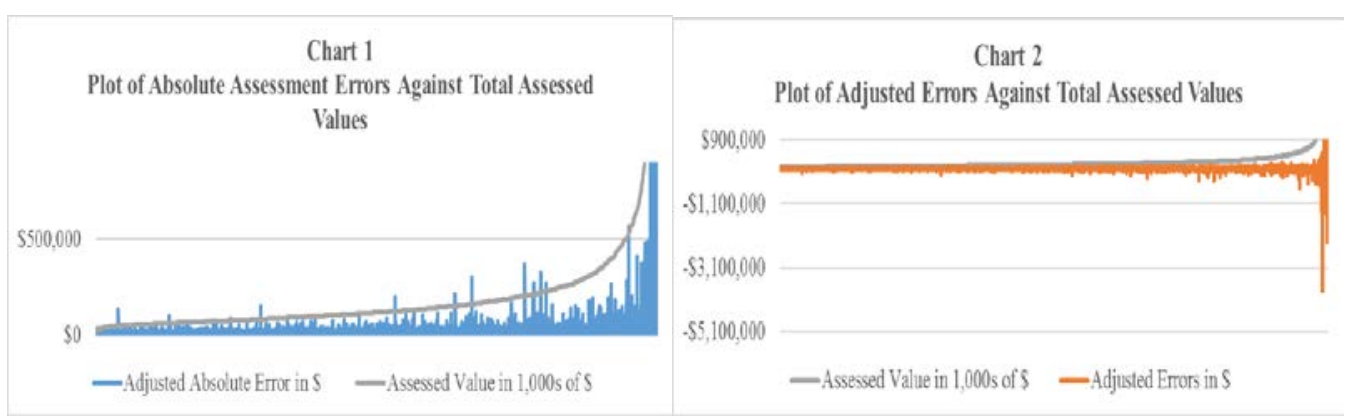




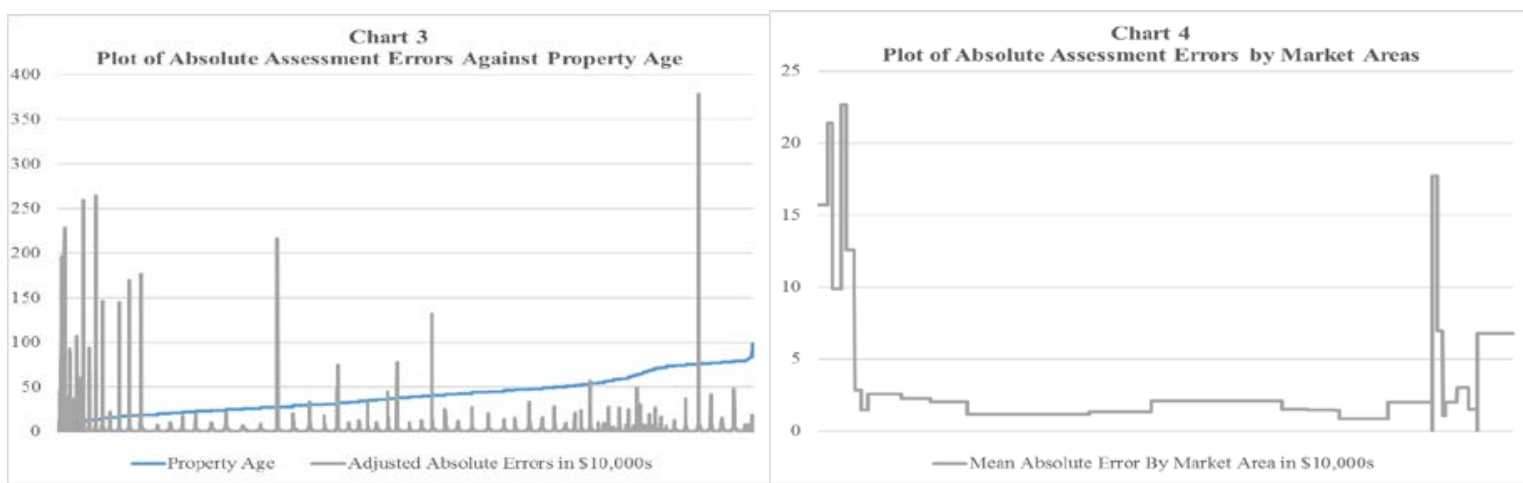

At the suggestion of an anonymous reviewer, several graphics may help the reader visualize the issue at hand in this study. For example, Charts 1 through 4 provide visual depictions of how assessment error varies in identifiable patterns within the sample data described later in this report. Chart 1 shows that the absolute value of assessment error rises with increasing property values, suggesting that more valuable properties present greater task complexity than less valuable properties. Chart 2 recognizes that errors may be positive or negative and shows that higher value properties are more likely to be underassessed relative to higher value properties. Notice that the bulk of assessment errors are negative, meaning that properties are far more likely to be underassessed than overassessed. Chart 3 shows that assessment errors tend to be larger in absolute magnitude for properties of lower age. This observation is consistent with the notion that initial assessments of value for "younger" properties present a more complex assessment task than more established properties. Chart 4 plots absolute assessment errors by market areas. The presence of a discernible pattern in the data suggests that assessment errors may be variable geographically within the taxing jurisdiction. These charts provide simple examples that support a more rigorous analysis of the determinants of assessment error as revealed below.

The next section of this paper describes sources of assessment error and briefly summarizes some of the previously published research related to assessment error (also referred to as appraisal error). The subsequent two sections describe the data collected for analysis and propose an analysis framework for investigating assessment error in the sample data, respectively. The final section provides a discussion of the results of the analysis and draws some conclusions based on the analysis.

\section{Sources of Systematic Assessment Error}

Although widely held opinions suggest that, as Geltner and Ling [1] imply, some degree of systematic bias is inherent in assessment practice, it is important to acknowledge here that two notable studies have examined the difference between observed transaction prices and assessors' (assessors) opinions of market value and found no systematic error. Cole, Guilky, and Miles [2] find no statistically significant difference between assessed value and transaction prices for commercial properties. Second, Dotzour [3] reports the same finding for residential properties. Numerous other researchers, however, have identified significant errors in assessors' opinions of value.

Task complexity is presumably the most important source of assessment error. Assessment error resulting from task complexity has frequently been considered in research studies relating to assessment equity in the property taxation literature (often considered there in the context of "horizontal inequity"), but the issue could apply in any assessment assignment. As the complexity of the assessment task increases, it is reasonable to suspect that the variation in assessment error could increase. This issue has long been of interest to property tax system analysts because many taxing jurisdictions levy property taxes on an ad valorem basis and errors in the assessment process can lead to properties within a given jurisdiction being subject to different effective tax rates even though the stated tax rate is the same for all properties in the jurisdiction. Several research studies have examined this issue for different property types, including Berry and Bednarz [4], Borland [5], Goolsby [6], Spahr and Sunderman [7], Smith [8], Allen and Dare [9], Cornia and Slade [10] and Cornia and Slade [11]. Other recent studies that consider various aspects and implications of assessment error include Zhu and Pace [12], Doerner and Ihlandfeldt [13], and Birch and Sunderman [14]. 
Allen and Dare [9] report that housing characteristics indicative of increased task complexity for the assessor are positively related to assessment difficulty (as measured by the variation around the mean assessment to transaction price ratio). These characteristics include lot size, living area size, age of the home, and the percentage of minority residents in the neighborhood. Similarly, Cornia and Slade [10], studying apartments, found that both the number of units in a complex and the geographic location of the complex increased the difficulty for assessors to value uniformly.

Clearly, all sources of assessment error discussed above are undesirable in the assessment process. The purpose of this study is to provide additional insights into the impact of task complexity on assessment accuracy using a large sample of properties for which assessments were prepared within 12 months after an arm's length transaction (with observed prices) for each property. The next section describes the data sample.

\section{Data Description}

The data used in this study were collected from the official property tax records of a large taxing jurisdiction in Florida and consist of multi-family properties that were sold at least once in a seven-year period. Each property in the sample is uniquely identifiable and information is available regarding the property's transaction price, physical characteristics (size in square feet, primary construction material, and construction quality rating), age, and location within the jurisdiction.

As required by state law, the conditions of each transaction were evaluated by the elected property assessor (or staff) for the jurisdiction to identify any specific circumstances that might indicate a nonarm's length transaction. Only those transactions determined to be "qualified" by the assessor are considered in the analysis.

\begin{tabular}{|c|c|c|c|c|c|c|c|c|}
\hline \multicolumn{9}{|c|}{$\begin{array}{c}\text { Exhibit 1 } \\
\text { Means of Selected Variables in the Samole Data } \\
\text { (standard deriations in Darentheses) }\end{array}$} \\
\hline & Pooled Sample & 1999 & 2000 & 2001 & 2002 & 2003 & 2004 & 2005 \\
\hline Asse ssed Val ue & $\begin{array}{r}310.695 \\
(1.682 .576) \\
\end{array}$ & $\begin{array}{l}139.135 \\
(394.682)\end{array}$ & $\begin{array}{r}197.557 \\
(968.608)\end{array}$ & $\begin{array}{c}250.989 \\
(1.216 .788)\end{array}$ & $\begin{array}{r}316.442 \\
(1.765 .201)\end{array}$ & $\begin{array}{r}286.036 \\
(1.544 .285)\end{array}$ & $\begin{array}{c}556.898 \\
(2.730 .018)\end{array}$ & $\begin{array}{r}391.920 \\
(1.935 .565)\end{array}$ \\
\hline Adjusted Sale Price & $\begin{array}{r}311,393 \\
(1.658 .280)\end{array}$ & $\begin{array}{r}145,004 \\
(441.134)\end{array}$ & $\begin{array}{r}202,479 \\
(1.002 .285)\end{array}$ & $\begin{array}{c}244,222 \\
(1.112 .101)\end{array}$ & $\begin{array}{r}319,343 \\
(1.726 .317)\end{array}$ & $\begin{array}{r}282,727 \\
(1.474 .430)\end{array}$ & $\begin{array}{r}553,713 \\
(2.680 .631)\end{array}$ & $\begin{array}{r}396,450 \\
(1.973 .425)\end{array}$ \\
\hline Aporaised Value to Adjusted Sale Price Ratio & 0.999 & 0.999 & 0.999 & 0.999 & 0.999 & 1.000 & 0.999 & 1.000 \\
\hline & $(0.16)$ & $(0.20)$ & $(0.19)$ & $(0.16)$ & $(0.13)$ & $(0.14)$ & $(0.16)$ & $(0.15)$ \\
\hline Absolute Assessment Error & $\begin{array}{r}28.378 \\
(123.776)\end{array}$ & $\begin{array}{r}19.977 \\
(57.706)\end{array}$ & $\begin{array}{r}22.876 \\
(85.639)\end{array}$ & $\begin{array}{r}29.047 \\
(144.976)\end{array}$ & $\begin{array}{r}30.933 \\
(175.474)\end{array}$ & $\begin{array}{r}22.722 \\
(96.865)\end{array}$ & $\begin{array}{r}38.067 \\
(160.255)\end{array}$ & $\begin{array}{r}33.034 \\
(101.135)\end{array}$ \\
\hline Under-A.sse ssed Indic ator & 0.504 & 0.505 & 0.486 & 0.475 & 0.486 & 0.481 & 0.536 & 0.549 \\
\hline & & & & & & & & \\
\hline Month of Sale & $\begin{array}{c}6.44 \\
(3.37)\end{array}$ & $\begin{array}{c}6.71 \\
(3.45)\end{array}$ & $\begin{array}{c}6.41 \\
(3.18)\end{array}$ & $\begin{array}{c}6.61 \\
(3.47)\end{array}$ & $\begin{array}{l}6.31 \\
(3.44)\end{array}$ & $\begin{array}{l}6.07 \\
(3.33)\end{array}$ & $\begin{array}{c}6.43 \\
(3.38)\end{array}$ & $\begin{array}{l}6.51 \\
(3.29)\end{array}$ \\
\hline Age & 40.43 & 32.18 & 37.88 & 39.49 & 40.57 & 41.23 & 43.29 & 46.30 \\
\hline & $(20.06)$ & $(15.47)$ & $(19.29)$ & $(19.52)$ & $(19.74)$ & $(20.31)$ & $(21.23)$ & $(20.82)$ \\
\hline Size & 5.312 & 3.663 & 4.611 & 5.148 & 5.760 & 4.723 & 8.506 & 4.763 \\
\hline & $(27.404)$ & $(8.701)$ & $(21.769)$ & $(23.603)$ & $(30.462)$ & $(25.458)$ & $(43.429)$ & $(25.585)$ \\
\hline Improvement Quality Raxing & 3.11 & 3.05 & 3.03 & 3.06 & 3.10 & 3.15 & 3.14 & 3.20 \\
\hline & $(0.52)$ & $(0.42)$ & $(0.35)$ & $(0.43)$ & $(0.53)$ & $(0.57)$ & $(0.54)$ & $(0.67)$ \\
\hline Land Assessed Value to Total Assessed Value Ratio & $\begin{array}{c}0.315 \\
(0.261)\end{array}$ & $\begin{array}{c}0.299 \\
(0.165)\end{array}$ & $\begin{array}{c}0.257 \\
(0.170)\end{array}$ & $\begin{array}{c}0.271 \\
(0.195)\end{array}$ & $\begin{array}{c}0.297 \\
(0.514)\end{array}$ & $\begin{array}{c}0.289 \\
(0.209)\end{array}$ & $\begin{array}{c}0.318 \\
(0.190)\end{array}$ & $\begin{array}{c}0.439 \\
(0.180)\end{array}$ \\
\hline Stee 1 & 0.004 & 0.009 & 0.009 & 0.005 & 0.005 & 0.000 & 0.001 & 0.001 \\
\hline & & & & & & - & & \\
\hline Concrete & 0.032 & 0.077 & 0.012 & 0.022 & 0.018 & 0.032 & 0.034 & 0.030 \\
\hline Wood & 0.313 & 0.222 & 0.304 & 0.323 & 0.318 & 0.317 & 0.340 & 0.353 \\
\hline & & & & & & & & \\
\hline Masonry & 0.651 & 0.692 & 0.676 & 0.650 & 0.659 & 0.651 & 0.625 & 0.616 \\
\hline Number of Observations & 5.000 & 653 & 675 & 737 & 657 & 693 & 709 & 876 \\
\hline
\end{tabular}

"Just" value of each property was estimated by the elected property assessor as of January 1 of each year as required by state law. Florida Statute 193.011(8) requires that "just" value for property tax purposes must reflect the "net proceeds of the sale of the property, as received by the seller, after deduction of all of the usual and reasonable fees and costs of the sale, including the costs and expenses of financing." Thus, we multiply the observed transaction price by the mean assessment ratio (mean just value divided by mean transaction price) from each geographic market within the taxing jurisdiction to account for the fees and costs of sale that would otherwise be reflected in the transaction prices. Descriptive statistics for the primary variables of interest in this study are presented in Exhibit 1. 


\section{Model Specification and Analysis Method}

The following functional model allows testing of the hypothesis that task complexity is a significant determinant of assessment error in this sample.

$$
\begin{aligned}
& \text { Assessment error }=\text { /adjusted transaction price - assessed valuel }=f[\text { task complexity }] \\
& \text { Adjusted Assessment Error }=\alpha+\beta_{1} \text { underassess }+\beta_{2} \ln (\text { Adjusted Sale Price })+\beta_{3} \text { Month of } \\
& \text { of Sale }+\beta_{4} \text { Age }+\beta_{5} \text { Size }+\beta_{6} \text { Quality Rank }+\beta_{7} \text { Steel }+\beta_{8} \text { Concrete }+\beta_{9} \text { Wood }+ \\
& \beta_{10} 2000+\beta_{11} y 2001+\beta_{12} y 2002+\beta_{13} y 2003+\beta_{14} y 2004+\beta_{15} y 2005+\beta_{16}(\text { Land } \\
& \text { Assessed Value to Total Assessed Value Ratio }+\beta_{17} \text { Imkar } 2+\ldots+\beta_{43} \text { Imkar99 }+\varepsilon,
\end{aligned}
$$

where the dependent variable is the absolute value of adjusted assessment error, $\alpha$ and $\beta$ are parameters to be estimated, and $\varepsilon$ is a random error term.

In this model, assessment error is defined as the absolute value of the difference between observed transaction price (adjusted as previously described) and the assessed value of each property and is hypothesized to be a function of the degree of the complexity of the assessment task as determined by various property characteristics. Hypothesis testing from the above model is possible by regressing assessment error on the hypothesized determinants of assessment error using Ordinary Least Squares (OLS).

The independent variables for task complexity are largely dictated by the data available from the property tax records. The available data include the size of each property, its age, its primary construction material, its construction quality rating assigned by the property assessor, its location within the jurisdiction, its total assessed value, and the assessed value of the land (separately from the improvements). Size is measured in square feet, age is measured in years at the time of the transaction, and construction quality rating is coded as dummy variables to indicate the property assessor's opinion of construction quality with possible ratings of minimum, below average, average, above average, excellent, and superior construction quality. Primary construction material is coded as dummy variables to indicate masonry, wood, steel, and reinforced concrete. Location is also coded as dummy variables for 28 geographic areas within the jurisdiction that have been identified as distinct market areas by the property assessor and that are represented in the sample.

To test the hypothesis that properties with greater market value pose a more challenging assessment task, the natural $\log$ of transaction price is also included in the regression. Taking the natural log of transaction prices reduces the obvious collinearity between transaction price and other variables in the regression equation. Additionally, the ratio of assessed land value to total assessed property value is included to address potential difficulties with appraising excess or surplus land. Residential properties usually sell with only slightly more than the minimum required lot size included, but there are exceptions. Some extra land is capable of being developed by itself. It is a common practice with the use of hedonic pricing models to guard against naïve inclusion of properties with extra land attached, by excluding them from the sample (see Hauren and Brasington [15]), by accounting (controlling) for the extra land in the regression analysis (see Jud and Winkler [16]), or some combination of both approaches (see Nelson, Genereux, and Genereux [17]).

An indicator value (underassess) taking the value of " 1 " when the sign of the assessment error is negative (and " 0 " otherwise) is included to indicate any relationship between the direction of assessment error and the magnitude of the error. This variable will be significant and positive if the size of the error is an increasing function of the assessor's tendency to underestimate value as opposed to overestimating value. In this sample, all of the assessments were prepared for tax assessment purposes by the elected property assessor (and staff) in a single taxing jurisdiction in Florida. In the current data sample, pressure will likely come from the property owners (voters) who prefer lower assessed values that will result in lower effective tax rates. Indeed, any overestimate of value will likely trigger a challenge to the assessment, but any underestimate of value will likely go unchallenged by the property owner. The elected property assessor for the jurisdiction thus potentially has strong incentive to underestimate value (as supported by Chart 2) as a way to gain or maintain popularity among self-interested constituents. Such advocacy, of course, has little if any consequence on the effective tax rate levied on property owners as long as all properties in the jurisdiction are assessed at the same proportion of value because the stated tax rate is set by the taxing authority (not the property assessor). This point has been 
previously raised by Goolsby [6] and Allen and Dare [9].

Finally, an important issue to be resolved before estimating the model involves the possibility that market conditions have changed between the date of the transaction and the effective date of the assessment. The data includes the month of transaction prior to the assessment date of January 1 of the following year. Thus, the month of sale (with values 1 through 12) can be used as a control variable indicating the currency of the property-specific data being used by the assessor to estimate value. More specifically, the price at which a property is sold as a result of an arm's length negotiation in the $12^{\text {th }}$ month (December) of the previous year contains more current (and accurate) information than one sold in month 1 (January) of the previous year. Admittedly, this variable is not a perfect proxy for changes in market conditions, but to the extent that changing market conditions may influence our measure of assessment error, the coefficient on this variable can be expected to decrease as the variable value increases. In other words, the impact of changes in market conditions can be expected to decrease for observations in this sample as the transaction date increases and draws closer to the assessment date.

To the extent that each of the above factors measure task complexity (or lack thereof), any positive (negative) significant coefficients on these variables would indicate that the factor is a determinant of assessment error (inaccuracy). In addition, the variable underassess is included to detect the direction of error resulting from client pressure and takes the value of 1 ( 0 otherwise) when the assessment error is negative. The control variable for changing market conditions between sale date and assessment date may provide additional insights into the determinants of assessment error in this sample.

\section{$5 \quad$ Results}

Estimating the model described above with OLS generates the results shown in Exhibit 2, Panels A and B. The model is estimated for the pooled data as well as for each of the seven years of the study period. In the pooled sample model, dummy variables for the year of assessment are included to control for variation in assessment error across the different years of the study period. In each regression, the omitted category for construction material is "masonry," and the omitted market area is "Imkar1."

\begin{tabular}{|c|c|c|c|c|c|c|c|c|}
\hline \multicolumn{9}{|c|}{$\begin{array}{l}\text { Exhibit 2: PanelA } \\
\text { RegressionAnalysis Results: } \\
\text { Dependent Variable }=\text { Adjusted Assessment } \text { E ror }\end{array}$} \\
\hline & \multirow{2}{*}{\multicolumn{2}{|c|}{$\begin{array}{l}\text { Full sample } \\
\text { Coeffient }\end{array}$}} & \multirow{2}{*}{\multicolumn{2}{|c|}{1999}} & \multirow{2}{*}{\multicolumn{2}{|c|}{2000}} & \multicolumn{2}{|c|}{2001} \\
\hline & & & & $t$-stat & & & Coefficient & $t-$ stat \\
\hline Under-Assessed & $3,151.04$ & 1.34 & $10,942.94$ & $4.10^{* * *}$ & $1,923.25$ & 0.42 & $-1,108.27$ & -0.21 \\
\hline $\ln$ (Adjusted Sale Price) & $28,998.34$ & 1200 & 1.465 .95 & 0.49 & $37,423.92$ & $8.26^{\circ * *}$ & $23,727.59$ & $4.31 \%$ \\
\hline Month of S ale & -89.99 & -0.26 & -225.16 & -0.60 & -200.07 & -0.28 & 664.78 & 0.86 \\
\hline Age & 182.43 & $2.29 * 4$ & 26.68 & 0.26 & -58.97 & -0.40 & 43.71 & 0.24 \\
\hline$S$ & 3.04 & $55.86 * *$ & 5.95 & $30.28 * *$ & 2.26 & $17.21 \%$ & 5.24 & $35.04 \%$ \\
\hline Quality Rank & $3,535.85$ & 1.39 & $15,438.28$ & $4.62^{* *}$ & $6,778.22$ & 0.98 & $10,217.45$ & 1.53 \\
\hline S teel & $-76,189.82$ & $-4.15 \%$ & $15,423.44$ & 1.14 & $-167,762.70$ & $-6.46^{4 *}$ & $-402,413.00$ & $-9.93 * *$ \\
\hline Concrete & $-17,016.82$ & $-2.2 * \omega$ & $5,793.41$ & 1.01 & $-22,196.53$ & -0.99 & $-52,252.82$ & $-2.61 \%$ \\
\hline Wood & $-1,600.86$ & -0.51 & $3,698.61$ & 1.05 & $5,417.31$ & 0.86 & -285.74 & -0.04 \\
\hline $\mathrm{y} 2000$ & $-1,799.83$ & -0.40 & - & - & - & - & - & - \\
\hline y2001 & $-1,395.90$ & -0.20 & - & - & - & - & - & - \\
\hline $\mathrm{y} 2002$ & $-3,180.04$ & -0.45 & - & - & - & - & - & - \\
\hline y2003 & $-10,834.56$ & -1.49 & - & - & - & - & - & - \\
\hline y 2004 & $-15,039.93$ & $-2.68 * 4$ & - & - & - & - & - & - \\
\hline y2005 & $-17,560.08$ & $-3.1 * 0$ & - & - & - & - & - & - \\
\hline I and Assessed Vabe to Total & & & & & & & & \\
\hline Assessed Valve Ratio & $20,182.91$ & $4.21^{* *}$ & $27,550.63$ & 2.9940 & $30,793.93$ & $2.21 \%$ & $83,943.59$ & 5.1904 \\
\hline Imkar2 & $8,119.76$ & 0.46 & (1) & 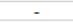 & & $x=$ & r & - \\
\hline Imkar3 & $-12,125.02$ & -0.80 & - & - & - & - & - & - \\
\hline Imkarts & $-17,741.60$ & $\begin{array}{l}-0.00 \\
-0.97\end{array}$ & - & 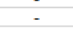 & $\because$ & $\because$ & - & $\because$ \\
\hline Imkars & $-10,612.91$ & -0.66 & $-74,507.73$ & $-8.25 * 4$ & - & - & - & - \\
\hline Imkkar6 & $-229,825.20$ & $-5.46^{* *}$ & 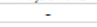 & - & - & - & - & - \\
\hline Imkar58 & $24,429.82$ & 1.48 & - & - & - & - & - & - \\
\hline Imkar59 & $34,390.17$ & $2.01^{4 *}$ & - & - & - & - & - & - \\
\hline Imkar60 & $24,441.46$ & $2.00 * 4$ & & & & & $-17,521.76$ & -0.41 \\
\hline Imkar62 & $33,416.71$ & $2.54^{* *}$ & 399.63 & 0.07 & $18,304.02$ & 1.12 & - & - \\
\hline Imkar63 & $34,779.17$ & $2.70^{* * 4}$ & 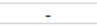 & - & 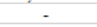 & - & - & - \\
\hline Imkar65 & $31,262.50$ & $2.81^{* *}$ & - & - & - & - & $-6,193.92$ & -0.15 \\
\hline Imkar67 & $35,764.03$ & $2.80^{4 *}$ & $-2,409.14$ & -0.49 & $17,541.59$ & 1.10 & - & - \\
\hline Imkar68 & $33,905.66$ & $2.80^{* * *}$ & $-1,949.90$ & -0.40 & $15,653.31$ & 1.00 & & - \\
\hline Imkar70 & $26,512.94$ & $2.17 * *$ & & & & & $-16,825.21$ & -0.40 \\
\hline Imkar72 & $26,834.28$ & $2.03^{* *}$ & $-5,270.82$ & -0.91 & $4,261.26$ & 0.26 & & \\
\hline Imkar73 & $26,889.80$ & 1.48 & - & - & & & & \\
\hline Imkar75 & $33,588.26$ & $2.88^{* 4}$ & - & - & $22,371.13$ & 0.37 & $8,105.72$ & 0.19 \\
\hline Imkarso & $22,627.99$ & $1.93^{*}$ & - & - & 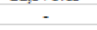 & - & $-9,600.54$ & -0.23 \\
\hline Imkar83 & $-25,749.15$ & -031 & - & - & - & - & & \\
\hline Imkar86 & $134,640.60$ & $7.74^{* *}$ & - & - & - & - & $-24,656.75$ & -0.51 \\
\hline Imkars9 & $32,200.41$ & $1.86^{*}$ & - & - & - & - & $-26,032.02$ & -0.51 \\
\hline Imkar91 1 & $52,636.91$ & $236^{* 4}$ & - & - & - & - & - & \\
\hline Imkar92 & $12,624.27$ & 0.92 & - & - & - & - & $-23,503.56$ & -0.54 \\
\hline Imkar93 & $15,859.72$ & 1.07 & - & - & - & - & - & \\
\hline Imkar94 & $37,150.24$ & $2.43^{* *}$ & - & - & - & - & $2,195.59$ & 0.04 \\
\hline Imkar96 & $-4,732.41$ & -0.06 & - & - & - & - & 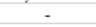 & $x_{1}$ \\
\hline Imkar99 & $47,337.22$ & $3.93 * 0$ & - & - & $29,164.02$ & $1.69^{*}$ & $-1,755.48$ & -0.04 \\
\hline constant & $-377,645$ & -12.54 & $-74,934$ & -2.27 & $-458,887$ & -8.20 & $-323,409$ & -4.34 \\
\hline & $156.15^{\circ *}$ & & $95.370^{\circ *}$ & & $52.91 \%$ & & $118.19 * *$ & \\
\hline$R$-square & 0.58 & & 0.69 & & 0.56 & & 0.77 & \\
\hline
\end{tabular}

** and * indicate significance at the 5 and 10 percent levels (or higher), respectively. 


\begin{tabular}{|c|c|c|c|c|c|c|c|c|}
\hline \multicolumn{9}{|c|}{$\begin{array}{c}\text { Exhibit 2: Panel B } \\
\text { Regression Analysis Results: } \\
\text { Dependent Variable = Adjusted Assessment Error }\end{array}$} \\
\hline & \multicolumn{2}{|c|}{2002} & \multicolumn{2}{|c|}{2003} & \multicolumn{2}{|c|}{2004} & \multicolumn{2}{|c|}{2005} \\
\hline & Coefficient & $t$-stat & Coefficient & $t$-stat & Coefficient & $t$-stat & Coefficient & $t$-stat \\
\hline Under-Assessed & $-1,651.73$ & -0.15 & $5,034.71$ & $2.20^{* *}$ & $10,961.21$ & $1.78^{*}$ & 156.57 & 0.05 \\
\hline In(Adjusted Sale Price) & $91,766.98$ & $7.8^{* *}$ & $15,413.42$ & $6.05^{* *}$ & $-3,169.91$ & -0.48 & $13,050.21$ & $3.76^{* *}$ \\
\hline Month of Sale & -10.11 & -0.01 & -329.42 & -0.97 & -246.82 & -0.27 & 105.19 & 0.22 \\
\hline Age & 920.65 & $2.34 * *$ & 105.22 & 1.37 & 458.18 & $2.22^{* *}$ & 166.62 & 1.46 \\
\hline Size & 1.11 & $4.14 * *$ & 4.11 & $66.01^{* *}$ & 3.42 & $32.17^{* *}$ & 3.49 & $47.32^{* *}$ \\
\hline Quality Rank & $31,516.14$ & $2.51^{* *}$ & $-1,084.96$ & -0.46 & $-6,290.73$ & -0.97 & $2,866.62$ & 1.04 \\
\hline Steel & $13,808.60$ & 0.16 & - & - & $72,336.52$ & 0.90 & $-263,212.90$ & $-5.84 * *$ \\
\hline Concrete & $-79,430.35$ & -1.53 & $22,027.10$ & $2.80^{* *}$ & $-12,275.38$ & -0.59 & $-22,199.90$ & $-2.09 * *$ \\
\hline Wood & $-16,026.76$ & -1.04 & -678.20 & -0.22 & $-15,089.38$ & $-1.85 *$ & $-7,860.61$ & $-1.86^{*}$ \\
\hline y2000 & - & - & - & - & - & - & - & - \\
\hline y2001 & - & - & - & - & - & - & - & - \\
\hline y2002 & - & - & - & - & - & - & - & - \\
\hline y2003 & - & - & - & - & - & - & - & - \\
\hline y2004 & - & - & - & - & - & - & - & - \\
\hline y2005 & - & - & - & - & - & - & - & - \\
\hline \multicolumn{9}{|c|}{ Land Assessed Value to Total } \\
\hline Assessed Value Ratio & $23,882.06$ & $2.14^{* *}$ & $14,116.03$ & $2.23^{* *}$ & $19,213.66$ & 1.03 & $33,471.24$ & $3.49 * *$ \\
\hline Imkar2 & - & - & - & - & $-40,174.22$ & -0.99 & $15,086.61$ & 0.33 \\
\hline Imkar3 & - & - & - & - & $-74,367.78$ & $-1.96 * *$ & $1,253.20$ & 0.03 \\
\hline Imkar4 & - & - & - & - & $-67,262.22$ & $-1.71 *$ & $7,589.58$ & 0.17 \\
\hline Imkar5 & - & - & - & - & - & - & - & - \\
\hline Imkar6 & $28,877.60$ & 0.31 & $-1,563,574.00$ & $-45.25^{* *}$ & - & - & - & - \\
\hline Imkar58 & - & - & - & - & $-35,732.22$ & -1.00 & $23,123.08$ & 0.52 \\
\hline Imkar59 & - & - & - & - & $-49,024.49$ & -1.30 & $19,519.49$ & 0.44 \\
\hline Imkar60 & $-31,188.42$ & -0.67 & $33,305.08$ & $4.44^{* *}$ & $-37,089.03$ & -1.09 & $26,144.30$ & 0.59 \\
\hline Imkar62 & - & - & - & - & $-37,377.23$ & -1.00 & $20,252.60$ & 0.45 \\
\hline Imkar63 & - & - & - & - & $-44,846.82$ & -1.33 & $24,201.31$ & 0.55 \\
\hline Imkar65 & $30,420.50$ & 0.76 & 31,307.81 & $4.91^{* *}$ & $-49,360.06$ & -1.40 & $15,947.41$ & 0.36 \\
\hline Imkar67 & - & - & - & - & $-50,576.75$ & -1.28 & $20,684.13$ & 0.45 \\
\hline Imkar68 & - & - & - & - & $-42,518.65$ & -1.27 & $24,199.30$ & 0.55 \\
\hline Imkar70 & $17,983.32$ & 0.42 & $30,428.86$ & $4.39 * *$ & - & - & - & - \\
\hline Imkar72 & - & - & - & - & $-38,038.66$ & -1.08 & $10,303.92$ & 0.23 \\
\hline Imkar73 & - & - & - & - & $-49,863.11$ & -1.34 & $17,450.07$ & 0.38 \\
\hline Imkar75 & $42,373.63$ & 1.00 & $28,584.92$ & $4.29 * *$ & - & - & - & - \\
\hline Imkar80 & $-36,570.34$ & -0.87 & $29,401.31$ & $4.25^{* *}$ & - & - & - & - \\
\hline Imkar83 & - & - & $-8,957.87$ & -0.30 & - & - & - & - \\
\hline Imkar86 & $274,264.20$ & $4.67 * *$ & $28,736.30$ & $2.80^{* *}$ & - & - & - & - \\
\hline Imkar89 & $-141,680.40$ & $-1.90 *$ & $29,022.16$ & $1.86^{*}$ & - & - & $64,485.76$ & 1.42 \\
\hline Imkar91 & - & - & - & - & $-50,377.26$ & -1.15 & $33,446.62$ & 0.72 \\
\hline Imkar92 & $-10,703.10$ & -0.23 & $19,791.49$ & $2.53^{* *}$ & - & - & - & - \\
\hline Imkar93 & - & - & - & - & $-25,857.78$ & -0.74 & $16,501.80$ & 0.37 \\
\hline Imkar94 & 49,957.36 & 0.75 & 36,693.41 & $2.75^{* *}$ & $-32,969.46$ & -0.89 & $19,549.15$ & 0.43 \\
\hline Imkar96 & - & - & - & - & $-63,957.20$ & -0.76 & - & - \\
\hline Imkar99 & $43,241.87$ & 1.01 & $26,417.12$ & 1.48 & - & - & - & - \\
\hline constant & $-1,207,374$ & -8.50 & $-210,842$ & -6.79 & 85,485 & 1.00 & $-194,424$ & -3.27 \\
\hline$F$-statistic & $18.16^{* *}$ & & 333.33** & & $87.49 * *$ & & $141.65^{* *}$ & \\
\hline$R$-square & 0.38 & & 0.91 & & 0.78 & & 0.82 & \\
\hline
\end{tabular}

** and ${ }^{*}$ indicate significance at the 5 and 10 percent levels (or higher), respectively.

$F$-statistics for each regression lead to the rejection of the null hypothesis that the coefficients are all equal to zero. Furthermore, the proportion of variation in assessment error in each regression that is "explained" by the model (as indicated by the $R^{2}$ ) is comparable to that of Allen and Dare [9] and Cornia and Slade [10].

In the pooled sample model, the results suggest that assessment error is an increasing function of transaction price, age of the property, size of the property, and the ratio of land value to total value. Assessment error is a decreasing function of steel and concrete construction in comparison to masonry, the omitted category of primary construction materials. Notably, the coefficient on the variable underassess is not significant. Assessment error in the pooled sample is significantly related to several of the market areas identified in the data.

Significance of the negative coefficients on the dummy variables for the years 2004 and 2005 suggest assessment error is smaller in recent years than it was in earlier years of the study period. Notably, the results provide no indication that the month of sale (with higher month of sale values indicating more recent data) is related to the magnitude of assessment error in the sample.

The regression results for each of the individual years in the study period suggest that assessment error is positively related to the direction of assessment error (the variable underassess) in three of the seven years considered, and that assessment error is an increasing function of transaction price in five out of seven years considered. Age and assessment error are positively related in three out of seven years. Size of the improvements is positively and significantly related to assessment error in each year except 2003 and 2005. The ratio of total land value to total assessed value is positively related to assessment error in six of the seven years considered in this study.

The coefficients on construction quality ratings indicate a significant (positive) relationship with the 
magnitude of assessment error in only one year of the study (1999). Similarly, coefficients on primary construction material provide conflicting results across the study years (compare "concrete" in 2003 with "concrete" in 2005). The coefficient on "steel" is negatively and significantly related to assessment error in 2000, 2001, and 2005. Location within various market areas within the jurisdiction is significantly related to assessment error in each year of the study period with the exception of 2001. As with the pooled sample, there is no support for the contention that changing market conditions between the most recent transaction date and the assessment date (within one year) is related to assessment error. As graciously noted by an anonymous reviewer, the high number of insignificant coefficients in the year-byyear regressions raises concerns about over-identification. Even so, the results are included in Table 2 to allow comparisons of results across years and with the pooled sample.

\section{Conclusion}

The results of this analysis provide support for the hypothesis that task complexity is a significant determinant of assessment error. The impact of client pressure to "under assess" is not particularly worrisome in this sample unless some client groups are able to impose disproportionate pressure in comparison to other groups. As the literature bears out, assessments done for different purposes seem to have their own built-in bias, and figuring the general propensities of assessors in each assessment setting, following the lead of Lentz and Wang [18], does not seem too difficult.

Some of the proxy variables used to capture potential error associated with task complexity (transaction price, age of improvements, size of the improvements, and location factors) are persistent and positive determinants of assessment error, but quality rank has almost no relationship with assessment error. The analysis presented here does not suggest that assessment error in this sample is affected by how recently the property involved was sold in an arm's length transaction.

Overall, this analysis confirms the common-sense notion that assessment accuracy could be improved by an increase in the competence of assessors facing complex assessment assignments, perhaps through improved training regarding the application of existing assessment methods or through improvement of the methods themselves. For decision-makers such as assessors, property owners, and other parties with an interest in accurate assessment of property values, this study emphasizes the importance of taking into consideration the complexity of the assessment task. This complexity may be affected by the size of each property, its age, its primary construction material, its construction quality rating assigned by the property assessor, its location within the jurisdiction, its total assessed value, and the assessed value of the land separately from the improvements. Being cognizant of the factors that affect assessment complexity may result in more accurate property tax value assessments.

\section{References}

1. Geltner, D. and D. Ling. "Considerations in the design and construction of investment real estate research indices," Journal of Real Estate Research, vol. 28, no. 4, pp. 411-444, 2006.

2. Cole, R., D. Guilky, and M. Miles. "Toward an assessment of the reliability of commercial appraisals," The Appraisal Journal, vol. 54, no. 3, pp. 422-432, 1986.

3. Dotzour, M. "Quantifying estimation bias in residential appraisal," Journal of Real Estate Research, vol. 3, no. 3, pp. 1-11. 1988.

4. Berry, B. and R. Bednarz. "A hedonic model of prices and assessment for single family homes: Does the assessor follow the market or the market follow the assessor?" Land Economics, vol. 51, no. 1, pp. 21-40, 1975.

5. Borland, M. "On the degree of property tax assessment inequity in complex tax jurisdictions," American Journal of Economics and Sociology, vol. 49, no. 4, pp. 431-438, 1990.

6. Goolsby, W. "Assessment error in the valuation of owner-occupied housing," Journal of Real Estate Research, vol. 13, no. 1, pp. 33-45, 1997.

7. Spahr, R. and M. Sunderman. "Property tax inequities on farm and ranch properties," Land Economics, vol. 74, no. 3, pp. 374-89, 1998.

8. Smith, B. "Applying models for vertical inequity in the property tax in a non-market value state," Journal of Real Estate Research, vol. 19, no. 3, pp. 321-344, 2000. 
9. Allen, M. and W. Dare. "Identifying determinants of horizontal property tax inequity: Evidence from Florida," Journal of Real Estate Research, vol. 24, no. 2, pp. 153-64, 2002.

10.Cornia, G. and B. Slade. "Assessed valuation and property taxation of multifamily housing: An empirical analysis of vertical and horizontal equity and assessment methods," Journal of Real Estate Research, vol. 27, no. 1, pp. 17-46, 2005.

11.Cornia, G. and B. Slade. "Horizontal inequity in the property taxation of apartment, industrial, office, and retail properties," National Tax Journal, vol. 59, no. 1, pp. 33-55, 2006.

12.Zhu, S. and R. Pace. "Distressed properties: Valuation bias and accuracy," Journal of Real Estate Finance and Economics vol. 44, pp. 153-166, 2012.

13.Doerner, W. M. and K. R. Ihlandfeldt. "An empirical analysis of the property tax appeals process," Journal of Property Tax Assessment \& Administration, vol. 11, no. 4, pp. 5-34, 2014.

14.Birch, J. W. and M. A. Sunderman. "Regression modeling for vertical and horizontal property tax inequity," Journal of Housing Research, vol. 23, no. 1, pp. 89-104, 2014.

15.Hauren, D. R., and D. Brasington "School quality and real houses prices: inter-and intra-metropolitan effects," Journal of Housing Economics vol. 5, pp. 351-368, 1996.

16.Jud, D. and D. Winkler. "The announcement effect of an airport expansion on housing prices," Journal of Real Estate Finance and Economics, vol. 33, pp. 91-103, 2006.

17.Nelson, A.C., J. Genereux, and M. Genereux. "Price effects of landfills on house values," Land Economics, vol. 68, no. 4, pp. 359-65. 1992.

18.Lentz, G. and K. Wang. "Residential appraisal and the lending process: A survey of issues," Journal of Real Estate Research, vol. 15, no. 1/2, pp. 11-39, 1998. 